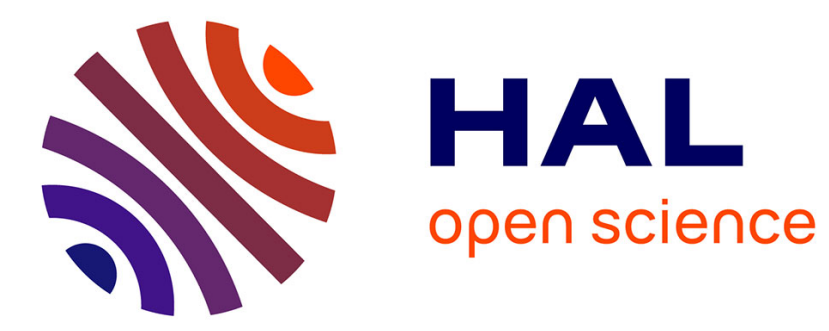

\title{
3D models related to the publication: Early Evolution of the Ossicular Chain in Cetacea: Into the Middle Ear Gears of a Semi-Aquatic Protocetid Whale
}

Mickaël Mourlam, Maeva Orliac

\section{- To cite this version:}

Mickaël Mourlam, Maeva Orliac. 3D models related to the publication: Early Evolution of the Ossicular Chain in Cetacea: Into the Middle Ear Gears of a Semi-Aquatic Protocetid Whale. MorphoMuseum, 2019, 10.18563/journal.m3.94 . hal-02367849

\section{HAL Id: hal-02367849 \\ https://hal.science/hal-02367849}

Submitted on 20 Nov 2019

HAL is a multi-disciplinary open access archive for the deposit and dissemination of scientific research documents, whether they are published or not. The documents may come from teaching and research institutions in France or abroad, or from public or private research centers.
L'archive ouverte pluridisciplinaire HAL, est destinée au dépôt et à la diffusion de documents scientifiques de niveau recherche, publiés ou non, émanant des établissements d'enseignement et de recherche français ou étrangers, des laboratoires publics ou privés. 


\title{
3D models related to the publication: Early Evolution of the Ossicular Chain in Cetacea: Into the Middle Ear Gears of a Semi-Aquatic Protocetid Whale
}

\author{
Mourlam Mickaël ${ }^{1 *}$, Orliac Maëva $J^{1}$ \\ ${ }^{1}$ Institut des Sciences de l'Évolution de Montpellier, cc64, CNRS, Univ. Montpellier, IRD, EPHE, 34095 Montpellier, France \\ ${ }^{*}$ Corresponding author: mickael.mourlam@umontpellier.fr
}

\begin{abstract}
This contribution contains the 3D models of the ossicles of a protocetid archaeocete from the locality of Kpogamé, Togo, described and figured in the publication of Mourlam and Orliac (2019).
\end{abstract}

Keywords: archaeocete, incus, malleus, stapes

Submitted:2019-09-24, published online:2019-10-01. https://doi.org/10.18563/journal.m3.94

$\begin{array}{llc}\text { Model IDs } & \text { Taxon } & \text { Description } \\ \text { M3\#407_UMKPGM73 } & \text { Protocetidae indet. } & \text { Stapes } \\ \text { M3\#408_UMKPGM73 } & \text { Protocetidae indet. } & \text { Incus } \\ \text { M3\#409_UMKPGM73 } & \text { Protocetidae indet. } & \text { Malleus }\end{array}$

Table 1. Protocetid inner ear ossicles. Collection: Université de Montpellier.

\section{INTRODUCTION}

The 3D models presented here are part of the protocetid whales specimens retrieved from the Lutetian bone bed of KpogaméHaotoé (Togo, 46 - 43 Ma; Cappetta and Traverse 1988; Gingerich and Cappetta 2014) and described by Mourlam and Orliac $(2017 \mathrm{a}, \mathrm{b}, \mathrm{c})$. The skull fragment UM-KPG-M 73 referred to as Protocetidae indeterminate (Mourlam and Orliac 2017a), allowed to realize the first description of the bony labyrinth morphology of protocetid whales (Mourlam and Orliac 2017b; Orliac and Mourlam 2017); this specimens also provides an unprecedented access to the tree ossicles composing the ossicular chain for a protocetid taxon (Fig. 1 A-B and table 1). Protocetid whales are transitional taxa between terrestrial and fully aquatic cetaceans and are a key for determining the hearing abilities of early whales. Data on their middle ear ossicles allows for refining our understanding of the first steps of the terrestrial/aquatic transition. The functional analyses of the different middle ear units of UM-KPG-M 73 reveal a mosaic pattern of terrestrial and aquatic signatures (Mourlam and Orliac 2019). This integrative anatomical and functional study demonstrates that protocetids had efficient hearing in both air and water.

\section{METHODS}

The 3D surface of the different ossicles of the ossicular chain of the skull fragment UM-KPG-M 73 was extracted slice-by-slice manually within AVIZO 9.0 (Visualization Sciences Group) with the limited range only option of the brush tool. The rather low resolution $(70 \mu \mathrm{m})$ and low contrast of the $\mathrm{CT}$ scan acquisition (Fig. 1 C-D), as well as the presence of sediment and recrystallization in the middle ear cavity are responsible for the limited quality of the resulting models. The 3D surface models are provided in PLY format, and can therefore be opened with a wide range of freeware.

\section{ACKNOWLEDGEMENTS}

We are grateful to M. Bouchet, C. Charles, and J. Martin for access to the AniRA-ImmOs (SFR Biosciences Gerland-Lyon) microtomography facility. Data presented in this work were produced through the technical facilities of the MRI platform member of the national infrastructure France-BioImaging supported by the French National Research Agency (ANR-10-INBS-04, «Investments for the future $\gg$ ), and of the Labex CEMEB (ANR10 -LABX-0004). This program is financially supported by the ANR program SPLASH (ANR-15-CE32-0010-01) headed by J.R. Boisserie and F. Lihoreau and the CeMEB project PygmHippoCom (coPi M. J. Orliac).

\section{BIBLIOGRAPHY}

Cappetta, H., Traverse, M., 1988. Une riche faune de sélaciens dans le bassin à phosphate de Kpogamé-Hahotoé (Éocène moyen du Togo): note préliminaire et précisions sur la structure et l'âge du gisement. Geobios 21(3), 359-365. https: //doi.org/10.1016/S0016-6995(88)80058-5

Gingerich, P. D., Cappetta, H., 2014. A new Archaeocete and other marine mammals (Cetacea and Sirenia) from lower middle Eocene phosphate deposits of Togo. Journal of Paleontology 88(1), 109-129. doi: https://doi.org/10.1666/13-040

Mourlam, M., Orliac, M. J., 2017a. Protocetid (Cetacea, Artiodactyla) bullae and petrosals from the Middle Eocene locality of Kpogamé, Togo: new insights into the early history of cetacean hearing. Journal of Systematic Palaeontology 16(8), 621-644. https://doi.org/10.1080/14772019.2017.1328378

Mourlam M.J., Orliac M.J. 2017b. Infrasonic and ultrasonic hearing evolved after the emergence of modern whales. Current 

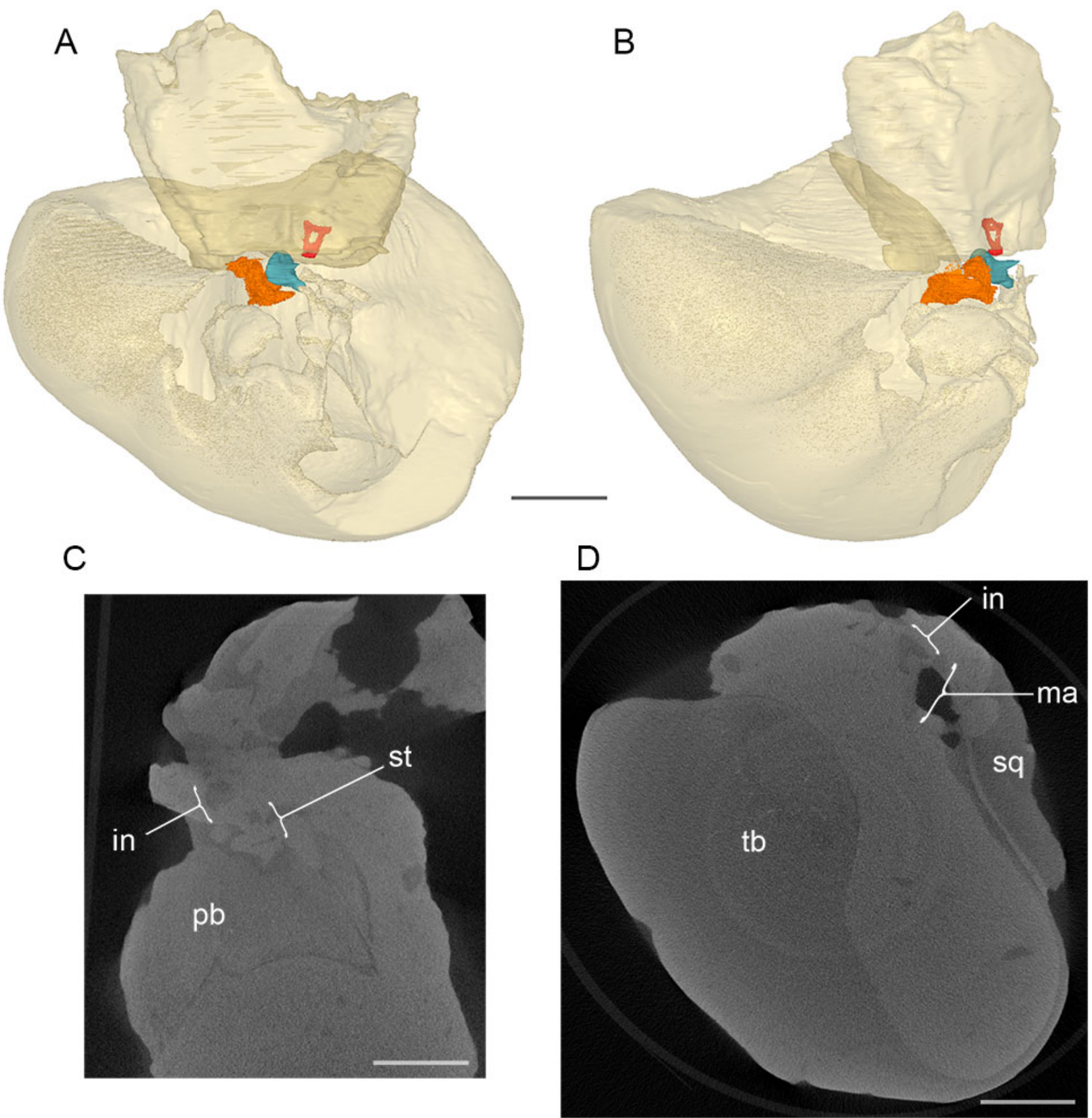

Figure 1. Location of the ossicular chain preserved within the middle ear cavity of protocetid indeterminate $\gamma$ (UM-KPG-M 73); A-B, 3D models of the middle ear in A) lateral and B) anterior views (red, stapes; blue, incus; orange, malleus; bony transparent elements, petrosal on top and tympanic bulla underneath), C-D, reconstructed slices showing the location of the ossicles; Abbreviations: in, incus; ma, malleus; pb, petrosal bone; sq, squamosal; st, stapes; tb, tympanic bulla. Scale bar $=10 \mathrm{~mm}$. 3D surfaces of the petrosal bones and bullae are available at MorphoMuseuM (Mourlam and Orliac, 2017c). 
Biology 27(12), 1776-1781. https://doi.org/10.1016/j.cub.2017. 04.061

Mourlam, M., Orliac, M. J., 2017c. 3D models related to the publication: Protocetid (Cetacea, Artiodactyla) bullae and petrosals from the Middle Eocene locality of Kpogamé, Togo: new insights into the early history of cetacean hearing. MorphoMuseuM 3(1)-e2. https://doi.org/10.18563/m3.3.1.e2

Mourlam M.J., Orliac M.J. 2019. Early Evolution of the Ossicular Chain in Cetacea: Into the Middle Ear Gears of a SemiAquatic Protocetid Whale. Proceedings of the Royal Society B. https://doi.org/10.1098/rspb.2019.1417

Orliac, M. J., Mourlam, M., 2017. 3D models related to the publication: Infrasonic and ultrasonic hearing evolved after the emergence of modern whales. MorphoMuseuM 3(2)-e4. https://doi.org/10.18563/m3.3.2.e4 